\title{
Weather and Climate Extremes on the Canadian Prairies: An Assessment with a Focus on Grain Production
}

\author{
E. Ray Garnett ${ }^{1, *}$ and Madhav L. Khandekar ${ }^{2}$ \\ ${ }^{1}$ Agro-Climatic Consulting, Canada \\ ${ }^{2}$ Former Environment Canada Scientist, Expert Reviewer IPCC 2007, Climate Change Documents, Canada
}

Copyright $\bigcirc 2017$ by authors, all rights reserved. Authors agree that this article remains permanently open access under the terms of the Creative Commons Attribution License 4.0 International License

\begin{abstract}
The Canadian prairies are Canada's granaries, producing up to 75 million tons of grain (primarily wheat, barley, and oats) and oilseeds (primarily canola) during the summer months of June to August. Canada is a major grain exporting country; exports have a market value of about 30-40 billion US dollars. The Canadian prairie agricultural industry is a major socio-economic activity for western Canada, employing thousands in farming communities and in other industries such as transportation on a year-round basis. A good grain harvest in a given year depends critically on various summer weather and climate extremes which can adversely or favorably impact grain yield and quality. Typical among such extremes that can impact crop yield and quality are: extended drought accompanied by heat; wet and cool summers; and frosts during sowing period (late May to early June) and during ripening (August) and the harvest period (late August to mid-October). This paper presents a number of examples of how extreme weather is implicated in grain production and quality estimates and annual exports. The paper analyzes some of the weather and climate extremes and their linkages to large-scale atmosphere-ocean circulation patterns. Among some of the important large-scale parameters that impact prairie summer weather are: the ENSO (El Nino-Southern Oscillation) phase in the equatorial Pacific, the MJO (Madden-Julian Oscillation in the eastern tropical latitude) and the PNA (Pacific North American) atmospheric flow pattern. Also detected is the impact of solar variability as identified by a geomagnetic index called the AP index (averaged planetary index). Please see Glossary of Terms in the Appendix.
\end{abstract}

Keywords Climatic Extremes, Canadian Prairie Grain, Teleconnections, Solar Influence

\section{Introduction}

The Canadian prairie provinces have an area of about 2 million square kilometers, an area greater than Spain and Portugal combined, and they make up about $20 \%$ of the total area of Canada. The prairie provinces are situated in western Canada; Canada extends from Victoria (British Columbia) in the west to St John's (Newfoundland) in the east. The current population of the three prairie provinces is now over 6 million, about $1 / 6$ th of the total population of Canada, about 36.5 million.

Figure 1 below shows four agricultural ecological zones [1]. The most suitable crops traditionally for these zones have been as follows: a) Peace River (PR)-barley, spring wheat and canola b) Palliser North (PN)-barley, canola and oats c) Palliser Brown (PB)-durum, spring wheat and lentils and d) Eastern prairies (EP)-spring wheat, soybeans and durum [2]. Wheat is still the largest crop grown on the Canadian prairies however canola has surpassed spring wheat in size. Barley is the third largest crop followed by durum wheat, soybeans and lentils.

Examining 1980-2009 normal data for the growing season months of May-July reveals that the hottest occur in the EP and $\mathrm{PB}$ zones (mean temperature $15.4^{\circ} \mathrm{C}$ ) and that the two coldest are the PR and PN zones (mean temperature $13.8^{\circ} \mathrm{C}$.). The two wettest are the EP and PN zones $(70 \mathrm{~mm})$ and the two driest are the PR and PB $(58 \mathrm{~mm})$. The numeric values are mean monthly averages. 


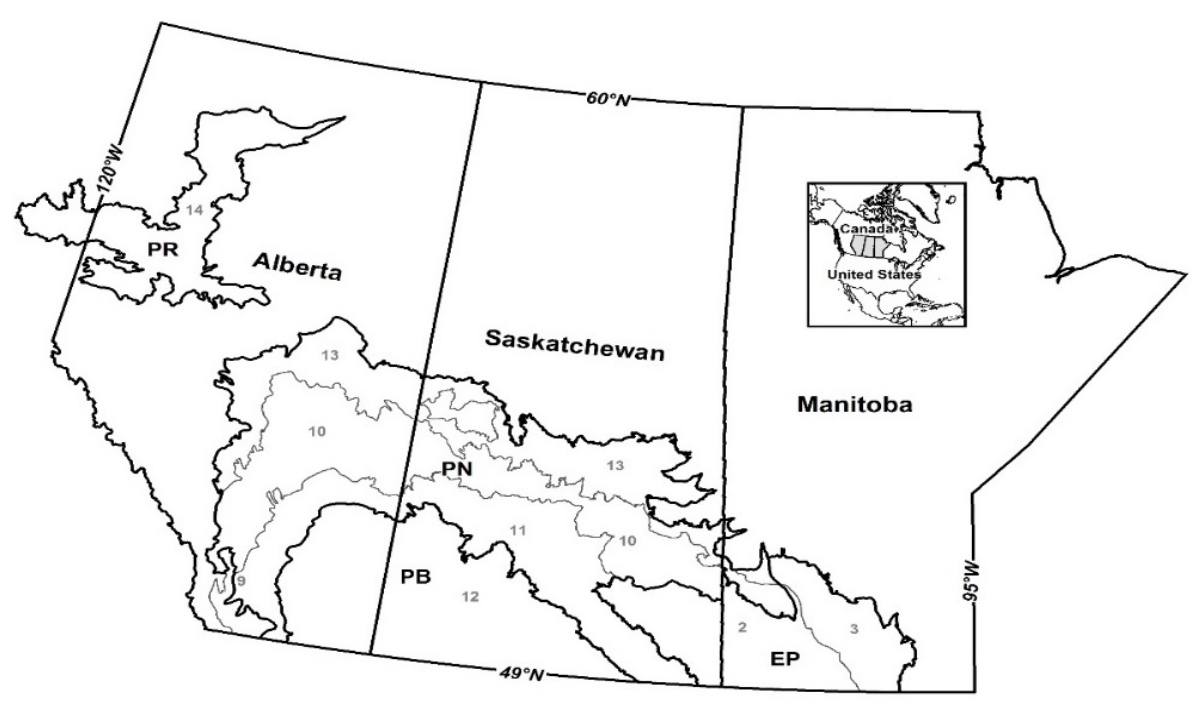

Figure 1. Agro-eco regions of the Canadian prairies (Padbury et al. 2002) reprinted with permission See text for more details on crops grown and the crop calendar

Most residents live in the southern prairies and enjoy a relatively mild winter. Most of the agriculture is cultivated in the southern regions (below about latitude 53N). The prairies often have a long and cold winter season from about mid-November till about mid-March. Winter temperatures can dip down to $-40^{\circ} \mathrm{C}$ on several days at various locations during the coldest month of January. Winnipeg (population over 750,000) and Saskatoon (population over 200,000) are among the coldest cities in Canada with December through February the coldest months. Total snowfall on the prairies is about $40 \mathrm{~cm}$ to $50 \mathrm{~cm}$ with most of snow falling during winter storms (often resulting in blizzards) which have their origin in the "Alberta Low" or "Colorado Low" in the lee of the Canadian-American Rocky Mountains. The city of Calgary (located at the foothills of the Rocky Mountains) often receives snowfalls during mid-September to mid-October in the wake of lee cyclones that develop east of the foothills. The snowfalls in the winter help somewhat in recharging the prairie soil moisture though the greatest recharge occurs in the autumn [3].

Heaviest rains on the prairies generally arrive in May through August with June-July rains the most critical in establishing crop yield. Most of the summer rains are in the form of thunderstorms and associated convective activity. Occasionally an easterly flow across the prairies can provide some (sporadic) moisture during the sowing period of May till early June [4]. Robertson [5] found that climatic factors explain $73 \%$ of spring wheat yield variation at Swift Current with leading determinants being June precipitation (26\%) and conserved moisture (14\%). Swift Current is located in the Palliser Brown (PB) zone.

During the first half of the $20^{\text {th }}$ century, some of the most severe and recurring droughts on the Canadian prairies were during the "dust bowl" years of the 1920s and 1930s. The drought years of 1919-21, 1929-1931 and 1936-37 have been well identified, especially in southeastern Alberta and southwestern Saskatchewan. This region of the Canadian prairies is part of the well-known Palliser Triangle (named after the British explorer Captain John Palliser) and is part of the Great Plains of North America. It consists of the Palliser Brown (PB) zone plus agro-eco regions 11 and 2 shown in Figure $1[6,7]$. As reflected in the different yield series that follow, the past 40 years have brought multi-year droughts in 1979-80, 1984-85, 1988-89 and most recently centered around 2001-2003 [7]. The years 1936 and 1937 were probably the most severe drought years on the Canadian prairies in the $20^{\text {th }}$ century $[7,8]$. It is noteworthy that Russia also had bad food growing years during 1936-1938 that resulted in several million Kulak farmers being executed for "underproduction" [9]. Sunspot activity peaked at 116 sunspots per month in 1937 and averaged 96 sunspots per month during 1936-1938.

The recurring droughts of the dust bowl years led to the creation of a Canadian government agency called PFRA (Prairie Farm Rehabilitation Administration) in 1935 to help the prairie farmers with agricultural and weather-related expertise [10]. The sporadic grain growing activity during the dust bowl years was firmly established by the mid-1940s and has become one of the most important socio-economic activities of the Canadian prairies. Severe droughts can affect Prairie agriculture as well as the national economy. Wheaton describes how the droughts of 2001 and 2002 reduced Canada's gross national product (GNP), which fell $\$ 5.8$ billion during 2001 and 2002, with the biggest loss occurring in 2002 at $\$ 3.6$ billion [11].

A number of papers have linked the recurring and often cyclical droughts to solar cycles and epochs of maximum solar tidal forcing of the atmosphere. The epochs appear to be highly correlated to the luni-solar induced precipitation and by extension to drought years in the U.S.-Canadian Great Plains region [12,13]. Recent studies [14-16] have attempted to link changing solar radiation to climate forcing and 
possibly to recurring droughts of the 1920s and 1930s. The issue of human induced global warming or climate change and varying solar radiation is being intensely debated at present [17-18] and is beyond the scope of the present study. We will, however, be referring to the impact of solar variability on Canadian Prairie summer weather and how it has affected affairs in some other parts of the world.

Curry and Venkatarangan [19] found that annual precipitation over the Canadian prairies is above normal near sunspot minima and below normal near sunspot maxima. Annual rainfall over the prairies is $445 \mathrm{~mm}$ with $200 \mathrm{~mm}$ or $45 \%$ of that occurring during the key growing season months of May to July. Garnett et al. [20] reveal that fewer than 70 sunspots per month tend to favor May to July rainfall while more than 105 sunspots tend to be unfavorable and develop a conceptual model whereby wet (dry) summers occur with low (high) sunspot activity, which increases (reduces) incoming cosmic rays, ions, condensation nuclei and cloudiness. Their findings are consistent with the global studies of cloud forcing by Svensmark and Friis-Christensen [21] and Svensmark and Calder [22].

Extreme weather events have also affected grain yields internationally of which $1972 / 73$ is a good example. The strong El Nino that onset in the spring of 1972 lasted a year and was a factor in the severe summer monsoon deficit in India which reduced rice production. Similarly, the El Nino played a role in Australia's drought that year sharply reducing wheat production. [23]. The Russian grain crop in 1972 was also a disaster. Russian traders quietly bought grain in the United States making small deals with suppliers all over the country which added up to a huge total. Had the
Russians not kept the matter quiet, prices would have shot sky high [9]. The Russian maneuver has often been described as the "Great Grain Robbery. In 2002 record wheat yields of 2.82 tons per hectare were achieved in Argentina related to strong El Nino conditions which simultaneously decimated Australian wheat crop following an Indian summer monsoon failure. Argentinean 2003 wheat yields dropped $16 \%$ a year later.

\section{Data and Methodology}

The primary goal of this paper is to describe how various climatic extremes have impacted grain production (area, yield and quality factors) in recent decades and explain the reasons for these impacts. A secondary goal is to draw attention to the possible impact of currently declining solar activity on future weather and grain production in particular. The various datasets used in this study are listed in Table 1 below. The source Agro-Climatic Consulting refers to a data set compiled by the first author's home-based business.

This is an observational study that uses linear trend, composite and correlation analysis. Grain yield data for the last 56 years is used to analyze year-to-year yield variability related to weather conditions. A trend line of grain yields is used to identify yields above and below trend and their linkage to weather and climate extremes. Correlation coefficients between grain yields and weather parameters are used in this study, some of which have come from earlier research.

Table 1. Data sets used in this study

\begin{tabular}{|c|c|c|c|}
\hline Data Type & Source & $\begin{array}{c}\text { Number of } \\
\text { stations }\end{array}$ & Record Length \\
\hline Monthly Precipitation* & Environment Canada & 400 & $1960-2004$ \\
\hline Monthly Precipitation* & Agriculture/Agri-Food Canada & 105 & $2005-2009$ \\
\hline Monthly Precipitation* & Agro-Climatic Consulting & 31 & $2010-2015$ \\
\hline Monthly Temperature* & Environment Canada & 400 & $1960-2004$ \\
\hline Monthly Temperature* & Agriculture/Agri-Food Canada & 105 & $2005-2009$ \\
\hline Monthly Temperature* & Agro-Climatic Consulting & 31 & $2010-2015$ \\
\hline Spring wheat yields* & Statistics Canada & $1960-2016$ \\
\hline Canola yields * & Statistics Canada & $1960-2016$ \\
\hline Barley yields * & Statistics Canada & $1960-2016$ \\
\hline U.S.D.A. & & $1972-2016$ \\
\hline U.S. Hard Red Winter Wheat Yields & Climate Prediction Center Washington, D.C. & $1950-2009$ \\
\hline Monthly NAO & Climate Prediction Center Washington, D.C. & & $1950-2009$ \\
\hline Monthly Nino 3.4 SST & National Geophysical Data Center & & $1750-2016$ \\
\hline Monthly sunspot data & National Geophysical Data Center & & $1933-2015$ \\
\hline API & & & \\
\hline
\end{tabular}




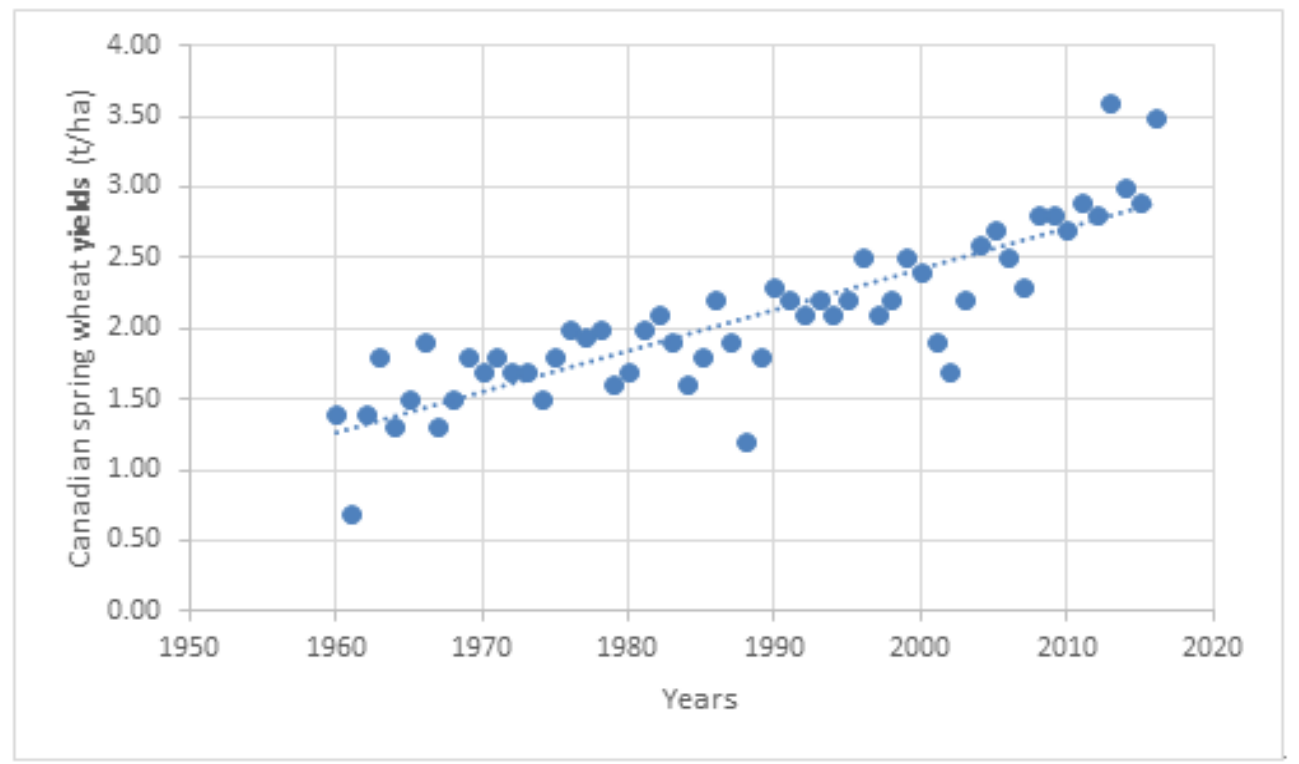

Source: Statistics Canada

Figure 2. Spring wheat yields for the period 1960-2016

\section{Results and Discussion}

Figure 2 shows how Canadian prairie spring wheat yields have fluctuated from 1960 to 2016 . One standard deviation (S.D.) from the mean is 0.50 . Serious droughts occurred in 1961, 1988, 2002, 2001 and 1984 such that yield shortfalls from previous records were $60 \%, 43 \%, 32 \%, 25 \%$ and $24 \%$ respectively. Conversely, very favorable growing season weather and improving technology resulted in record to very good yields in 2013, 1966, 1963 and 2016. In 2013 and 1966 yields exceeded previous records by $124 \%$ and $106 \%$ respectively.

How does heat and moisture stress affect spring wheat yields? Why the focus on the months of May-July? Peterson [24] describes the growth stages of cereals in which the four main phases are tillering, stem extension, heading, and ripening. The first critical stage is tiller initiation and development, which normally takes place in May. Heading is the last critical stage which typically occurs in July, when the effect of moisture stress is not as severe as at tillering, however is more sharply defined because there is less chance of recovery at this stage. If a flower aborts in July, that amount of potential yield is lost. Greatest water use in Saskatchewan occurs in July [25]. Ripening typically occurs in August when crops can be vulnerable to excessive rain and/or frost.

The greatest impacts on spring wheat yield in the last 50 years came in 1961 and 1988 when June temperatures over Saskatchewan and the Canadian prairies climbed to greater than 2 S.D. above normal, withering spring wheat at stem extension [26, 27]. In the months leading up to May-July of 1961 and 1988 Pacific North American (PNA) and Pacific Decadal Oscillation (PDO) indices were positive in 12 of 16 and 15 of 16 months respectively, bringing persistent meridian flow, which forced a ridging pattern over North America. This heat is reflected in Figure 3(a) below.
The 1961 drought came three years after the sunspot peak of 202 sunspots per month in 1958. The 1988 drought followed an El Nino and a drought monsoon in India in 1987 and came with a flood monsoon in India and La Nina conditions in 1988[23]. The 1988 drought came two years prior to the solar peak of 154 sunspots per month in 1990 . The 2001 and 2002 droughts were associated with a combination of La Nina and high solar activity. The 2001 drought was largely a consequence of La Nina conditions that persisted December through May. June and July in Saskatchewan during 2001-2003 were drier and warmer than normal [28]. The reduced yields in 2002 came as a result of a dry May, poorly distributed rains in June, a dry hot July and excessive rains in August at ripening. The excessive rains in August can be explained by the slow El Nino onset that year. The 2001 and 2002 droughts occurred the second and third year after the solar peak of 128 sunspots per month in 2000 which aggravated the situation. The main driver behind the reduced yields in 1984 and 1985 was persistent La Nina conditions December through May in both years.

Rapidly warming sea surface temperatures at Nino 3.4 between the winter and summer months in 1963 and persistently strong El Nino conditions between the winter and to summer months in 1966 were behind above normal June-July rainfall in those summers. Low solar activity $(<60$ sunspots per month) also favored growing conditions in those years. Low solar activity, a westerly phase of the Quasi-Wind Oscillation, low April North American snow cover and persistent zonal flow related to negative PNA and PDO indices brought ideal growing conditions in 2013 [20, 27]. In 2016 low solar activity, westerly stratospheric winds, El Nino conditions and below normal North American snow cover in April synergistically favored May-July growing conditions. The heavy June-July rainfall that favored bumper yields is reflected in Figure 3(b) below. 


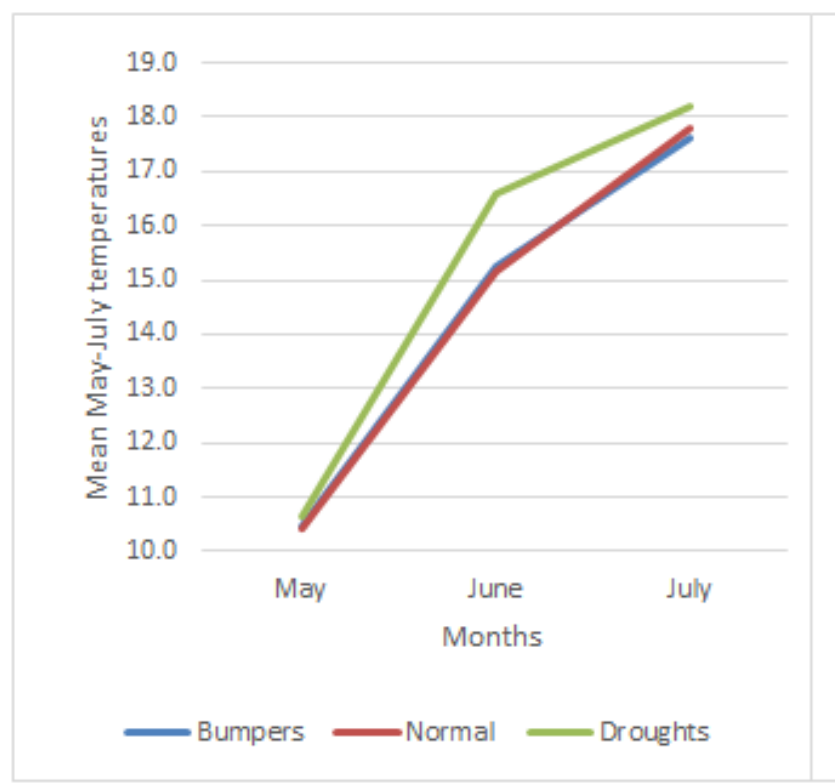

3 (a)

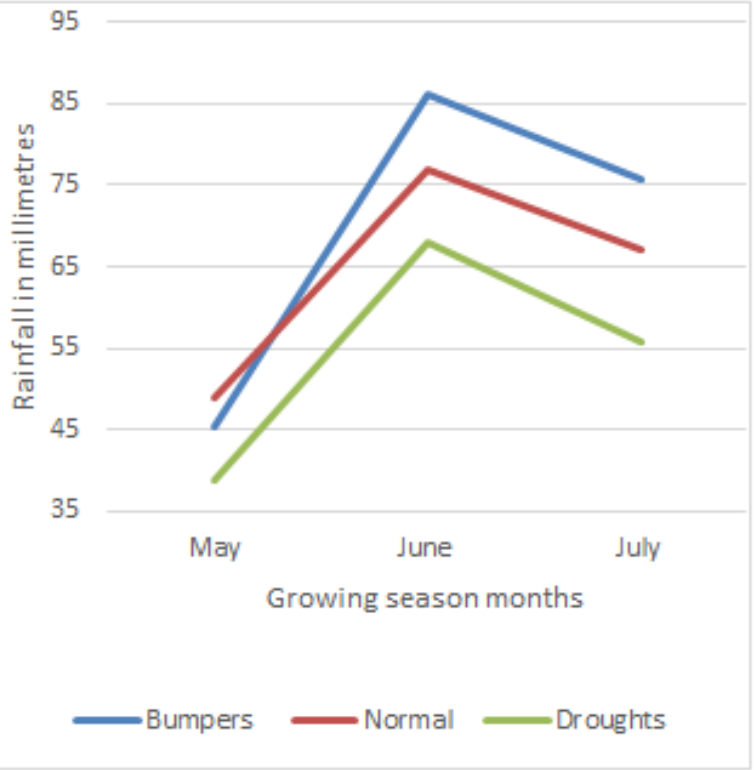

3 (b)

Figure 3. Composites of growing season temperature and rainfall in years of excellent yields (1963, 1966, 2013 and 2016) and drought affected yields $(1961,1984,1988,2001$ and 2002). Normal temperature and rainfall is represented by the orange line, the mean for the period 1950-2016. The bumper yields of 1.76, 1.87, 3.60 and 3.50 tonnes per hectare in 1963, 1966, 2013 and 2016 averaged $10 \%$ above the previous record.

It requires an estimated 1,080 GDDS (about 96 calendar days) to bring hard red spring wheat to maturity [29]. For the period 1931-1960 the average date of the last spring frost for most of the grain growing area was before May 31 while the average date for the first autumn frost was after August 31 [2]. In a survey of 42 spring wheat harvests from 1954 and 1995 , frost damage was a degrading factor in 14 of 42 years or $33 \%$. The most notable frost affected harvests were 1964 , 1974, 1982 and 1992 [30]. The growing season of 1992 resulted in $79 \%$ of red spring wheat being graded in the bottom two grades of \#3 Canada Western and Canada Feed compared to the average of $30 \%$. Protein content was a record low $12 \%$ compared to the 42 -year mean of $13.5 \%$ [30]. August 1992 temperatures were the $7^{\text {th }}$ coldest for the period 1975-2016 and May to September the $4^{\text {th }}$ coldest for the period 1985-2015. Crops were delayed and there was severe and widespread frost damage. The 1991 Mt. Pinatubo volcanic eruption cooled the following summer temperatures to $2^{\circ} \mathrm{C}$ below normal [27].

In 1982, severe frost damage resulted in $48 \%$ of red spring wheat grading \#3 Canada Western and Canada Feed with average protein content of $13.5 \%$ [30]. August 1982 was the $8^{\text {th }}$ coldest in 41 years (1975-2015). Environment Canada's historical archives reveal that killing frosts of $-2.3^{\circ} \mathrm{C},-3.5^{\circ} \mathrm{C}$ and $-3.0^{\circ} \mathrm{C}$ occurred August 27 at Yorkton, Foam Lake and Preeceville in northeast Saskatchewan where the average date of first autumn freeze is before August 31.

The growing season of 1974 was colder than 1982: mean May-September temperatures averaged $13.3^{\circ} \mathrm{C}$ compared to $13.8^{\circ} \mathrm{C}$ in 1982 . Severe frost, weathering, and a wet harvest resulted in over half the hard red spring crop grading in the bottom two grades compared to the 41 -year average of $34 \%$ [30]. August and September temperatures were $2^{\circ} \mathrm{C}$ and $3{ }^{\circ} \mathrm{C}$ below normal respectively. Moreover, frost at ripening in August also hurt yields as depicted in Figures 2, 4 and 5.

Figure 4 shows the trend in Canadian prairie canola yields over the last 66 years. One standard deviation (1 S.D.) from the mean is 0.38 tonnes per hectare. A case could be made for fitting two linear trends through the yield data, one from 1960 to 2000 and another from 2000 to 2016 . The increase in yields between 2002 and 2016 can be attributed to the wet May-Julys of 2005-2014, the wettest decade for the period 1975-2015, when May-July rainfall averaged $69 \mathrm{~mm}$ per month. May-July temperatures cooled close to $1{ }^{\circ} \mathrm{C}$ between 2005-2014, also favoring yields. Figure 4 shows that yields in 1983, 1984, 1988 and 1989 were markedly below trend, probably related to June-July temperatures being above the 59 -year mean in each of those years.

To optimize yields in anticipation of a wet growing season it is recommended that canola be planted first, then oats, barley and wheat in that order [26]. The biggest increases in yields in relation to previous records occurred in 1977, 2013 and 1976 when the percentage increase was $18 \%, 15 \%$ and $13 \%$ respectively. Rainfall in May or June of those years exceeded $100 \mathrm{~mm}$ (>115\% of normal). The 2013 growing season was favored by low solar activity of 59 sunspots per month $(<70)$, a westerly phase of the Quasi-Wind Oscillation, low April North American snow cover and zonal flow induced by persistently negative PNA and PDO indices leading up to May-July [20, 27]. 


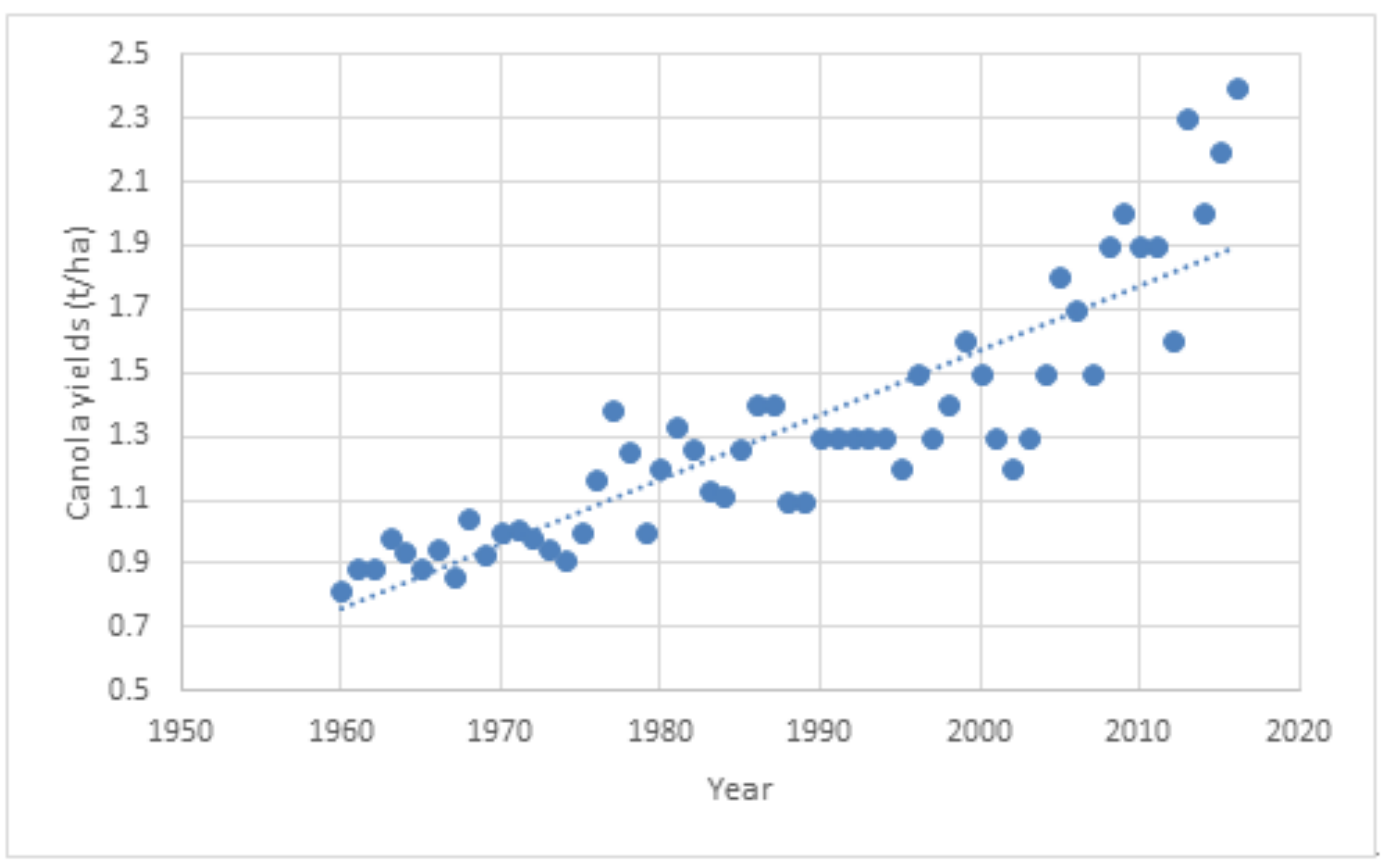

Figure 4. Canola yields for the period 1960-2016

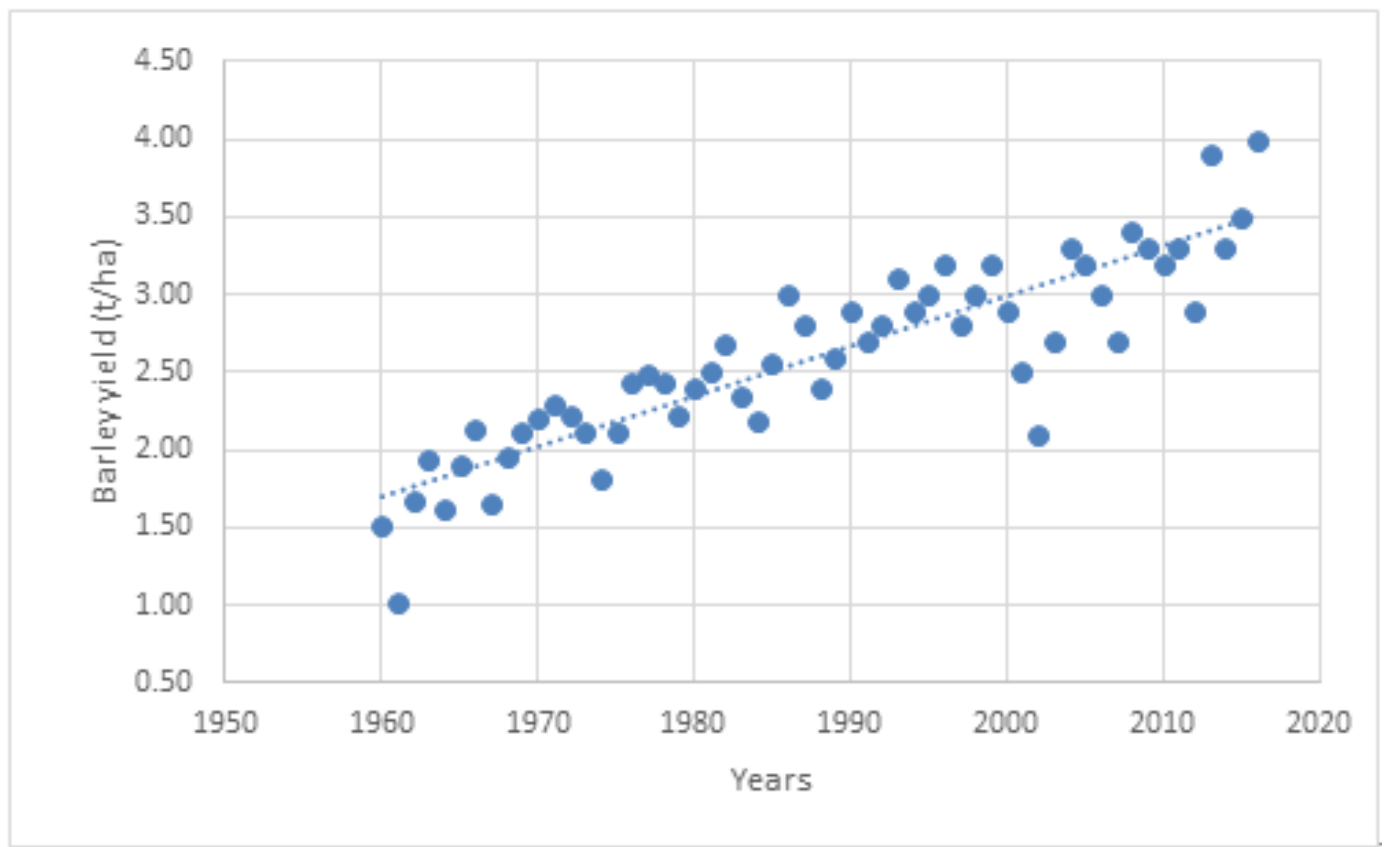

Figure 5. Canadian prairie barley yields for the period 1960-2016

The biggest adverse impact on canola yields came in 2002. A dry May and July along with poorly distributed heavy rains in June hurt prospects. A slow El Nino onset resulted in $173 \%$ of normal rainfall in August that hurt yields during ripening.

In anticipation of a dry hot summer, it recommended that wheat, barley, oats and canola be planted in that order to better resist drought [26]. It is also suggested that producers consider how much to spend on tillage, consider applying less nitrogen and consider planting the more drought-resistant lentil crop, generally the reverse strategy as for a wet, cool summer. The effect on different crops is apparent in Figures 2, 4 and 5 which show that spring wheat handled the 2001-2003 drought period better than canola and barley. July temperatures during 2001-2003 were 1 S.D. above normal. Those years May rainfall averaged $78 \%$ of normal. July heat and June-July dryness reduced 2003 canola yields. Sunspot activity was relatively high during 2001-2003, averaging 98 sunspots per month. The 115 sunspots in 2002 came two years after the peak of 118 sunspots per month in 2000. High solar activity reduces low-level cloudiness globally [21,22]. 
The trend in barley yields for the period 1960-2016 is found in Figure 5. It is important to point out that Alberta is the leading producer of barley with $50 \%$ of Canadian prairie production, followed by Saskatchewan with $25 \%$ and Manitoba at $13 \%$ [2]. Barley does not handle heat well, has a shorter growing season of about 90 days and its major growing area is concentrated further north and west of spring wheat and canola [2]. The deviation from the mean barley yields was higher than for spring wheat and canola with one standard deviation (S.D.) at 0.60 .

The biggest impacts on barley yields came in 1961 and 2002. June-July temperatures in 1961 averaged $18.6^{\circ} \mathrm{C}$, the second hottest for the period 1950-2009. Tremendous June-July heat is being attributed to positive Pacific North American (PNA) and Pacific Decadal Oscillation North American (PDO) indices both being positive at least at least 12 of 16 months leading up to the May-July period in those two years.

In 2002 June and July temperatures were more than 1 S.D. above normal. May, June and July rainfall was $67 \%, 127 \%$ and $89 \%$ of normal respectively. The June rains were poorly distributed and oriented towards the eastern prairies. Modeled plant-available water (PAW) revealed that severe shortages were apparent that summer in central Alberta and northwestern Saskatchewan [31].

Factors behind the May and July dryness in 2002 were above normal North American snow in April, high sunspot activity of 115 sunspots per month and an easterly phase of the QBO in September-November as set forth by Garnett et al. [20]. A slow El Nino onset led to untimely and excessive rain at ripening in August, reducing yield prospects.

Outstanding barley yields were experienced in 1986 and 2013. Ample July rains of $112 \mathrm{~mm}$ ( $193 \%$ of normal) in 1986 and June rains of $91 \mathrm{~mm}(115 \%$ of normal) in 2013 were key factors. The wet May-July of 1986 (124\% of normal) is being attributed to a westerly phase of the QBO, below normal North American snow cover in April and extremely low sunspot activity of 13 sunspots per month, which was conducive to increased low level cloudiness [21, 22]. In 2013, relatively low solar activity of 66 sunspots per month $(<70)$, a westerly phase of the QBO, below normal North American snow cover in April and persistent zonal flow with negative PNA and PDO indices brought ideal growing conditions $[20,27]$.

Figure 6 shows the high variance of U.S. hard red winter wheat yields for the period 1972-2016. One standard deviation from the average is 4.2 bushels per acre. The U.S. in 2016 was the fifth largest wheat producer and second largest exporter at 26 million tonnes after Russia (30 million tonnes) and slightly ahead of the European Union (25 million tonnes) [32].

Very strong El Nino conditions in December to March of 1982-83, 1997-98 and 2015-16 were evidently behind the record yields in 1983, 1998 and 2016. Correlations between El Nino $3.4^{\circ} \mathrm{C}$ sea surface temperatures and U.S. hard red winter wheat yields in the December-May period range from 0.23 in January to 0.28 in April with March-April correlations statistically significant at the 5\% level of significance during 1972-2009. Allan et al. [33] discuss how El Nino and La Nina affect the southern U.S. climate, particularly Texas.

The biggest percentage drop from the previous records occurred in 1989 at $30 \%$ and in 2002 by $26 \%$. The 1989 drought can be partly linked to persistent high solar activity of 147 sunspots per month and La Nina conditions December through April. A strongly positive NAO in January, February and May is hypothesized as restricting the Gulf of Mexico moisture. (Please see Appendix Glossary regarding the North Atlantic Oscillation and Bermuda High.) Garnett [26] refers to Bermuda High and its role determining U.S. rainfall distribution. In 2002, high sunspot activity of 115 sunspots per month and a strongly positive NAO in April during stem extension are considered as factors behind the reduced yields.

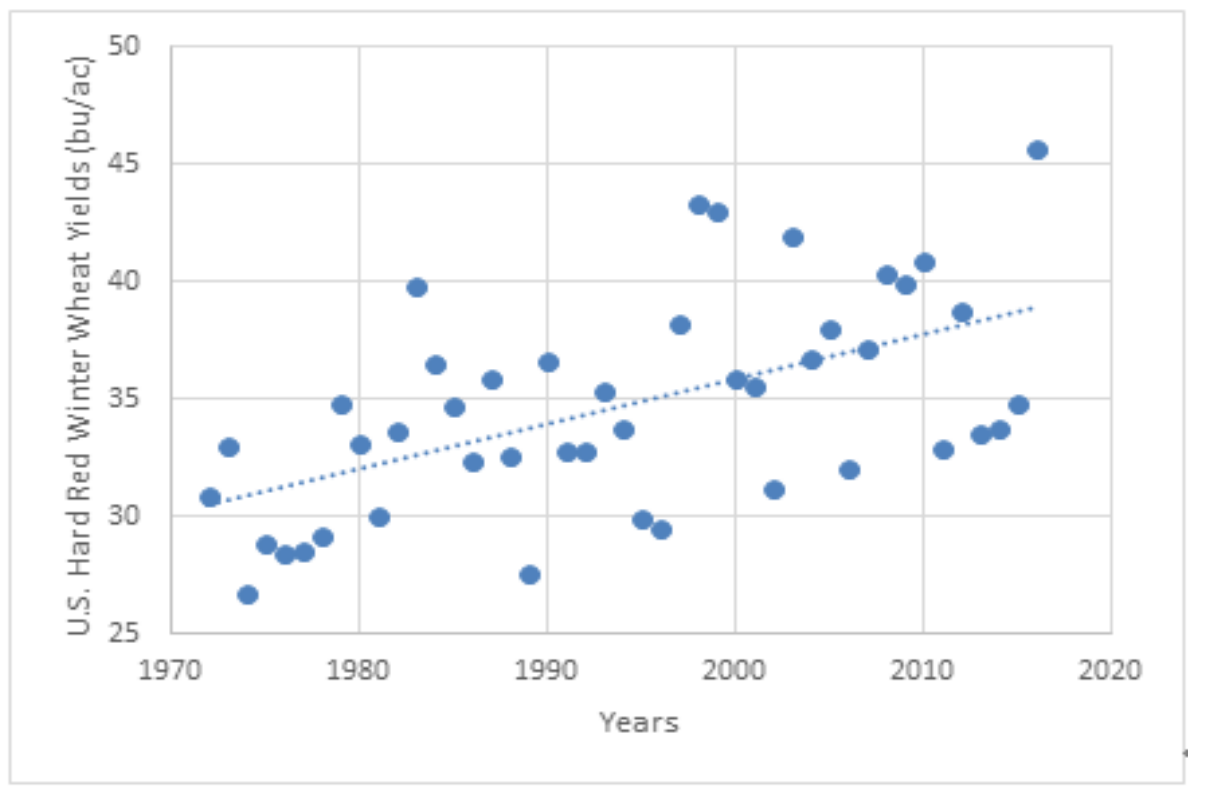

Figure 6. U.S. hard red winter wheat yields 1972-2015 


\subsection{Long-Term Implications of Solar Activity for Canadian Prairie Agriculture}

The Sun, besides being the source of life on planet Earth, also influences our weather and climate. Figure 7(a) shows how sunspot activity has declined during 1985-2015 and reveals 11-year sunspot cycles \#22 (1986-1995), \#23 (1996-2009) and \#24 (2010-present). Figure 7(b) reveals a more pronounced decline in the AP index or geomagnetic index than with sunspot activity. Georgieva et al. [34] demonstrate that the AP index is more representative of solar influence than a monthly count of sunspots and hence can be used as a proxy variable for solar variability. The API is defined as the earliest occurring maximum 24-hour value of a geomagnetic storm event obtained by computing an eight-point running average of successive three-hour AP indices. Over many years, the values of the AP index provide a maximum disturbance measure useful for identifying major geomagnetic storms chronologically and by amplitude from largest to smallest (Online available: http//Climate for You/Sun/AP index).

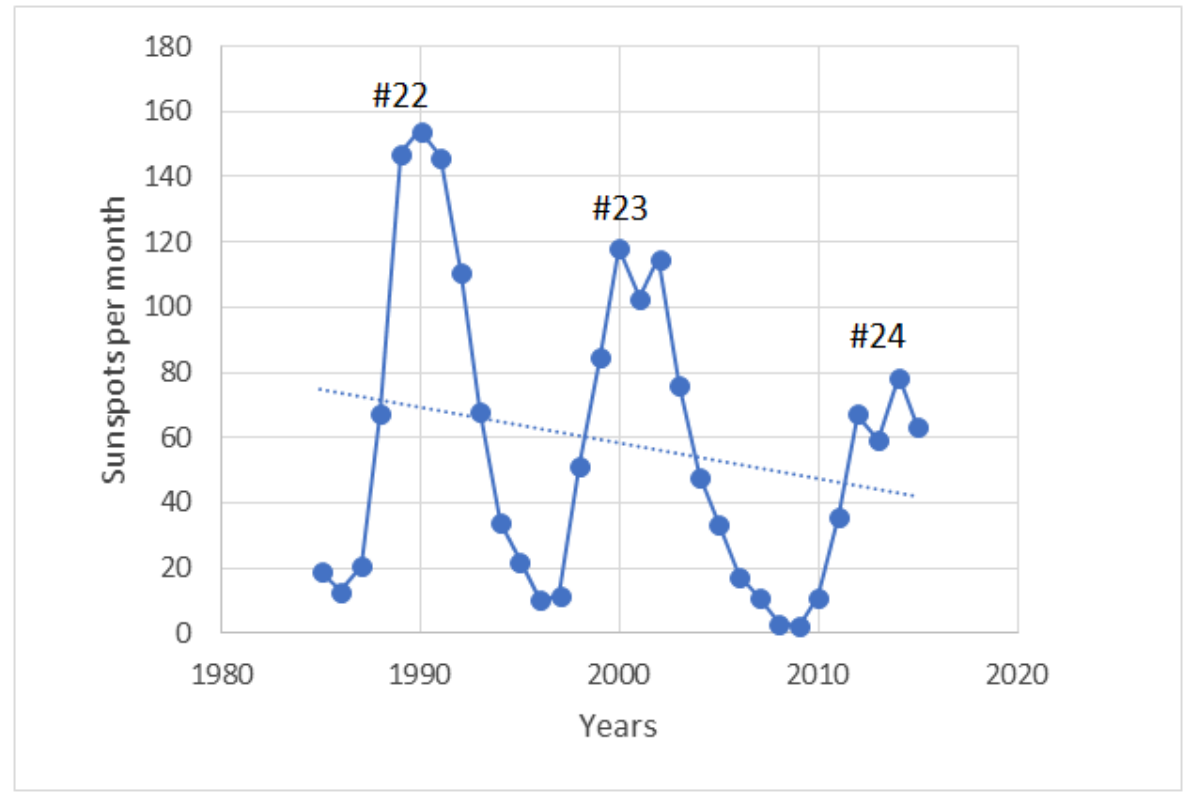

Figure 7(a). Mean monthly sunspot activity 1985-2015

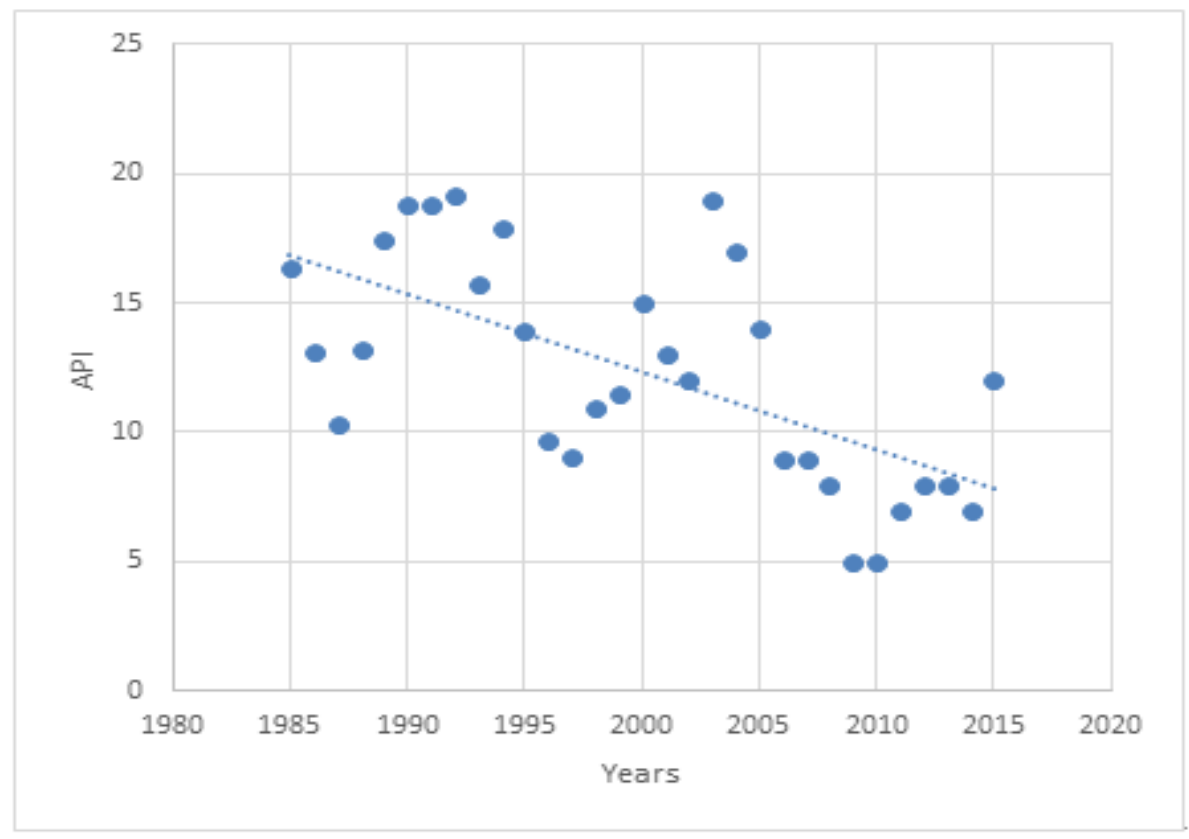

Figure 7(b). Mean monthly API index 1985-2015 
Hughes et al. [35] write that the sun controls the temperature of the earth and state that $\mathrm{CO}_{2}$ has nothing to do with the temperature of the earth. Carbon dioxide is a tiny fraction of the atmosphere at $0.04 \%$. It is essential to life on this earth, with sunlight plus water plus $\mathrm{CO}_{2}$ the basic process that creates all plants. Photosynthesis keeps us alive. Hughes et al [35] link increased grain yields to a more carbon dioxide rich environment, which appears to be borne out by increased grain yields in developing nations, in particular, where grain yields have doubled in the last 30 years. Archibald [36] states that the length and weakness of solar cycles can affect global mean temperatures and this possibility should be taken into account in future projections of mean temperature and grain production.
Figures 8(a) and 8(b) reveal how May-July and May temperature have cooled over the Canadian prairies between 1985 and 2015 . The May decline is $2.8^{\circ} \mathrm{C}$ and May-July $1.5^{\circ} \mathrm{C}$. The May-September temperature decline is somewhere between these two values. The greatest cooling for that time period has occurred in May and June and has been most pronounced in the Palliser North and Eastern Prairie zones shown in Figure 1. When the Pinatubo volcano-influenced years of 1992 and 1993 are treated as outliers, the correlation between the mean monthly API shown in Figure 7(b) and Canadian prairie May-July temperatures shown in Figure 8(a) is $0.33(\mathrm{n}=29)$ significant at the $5 \%$ level.

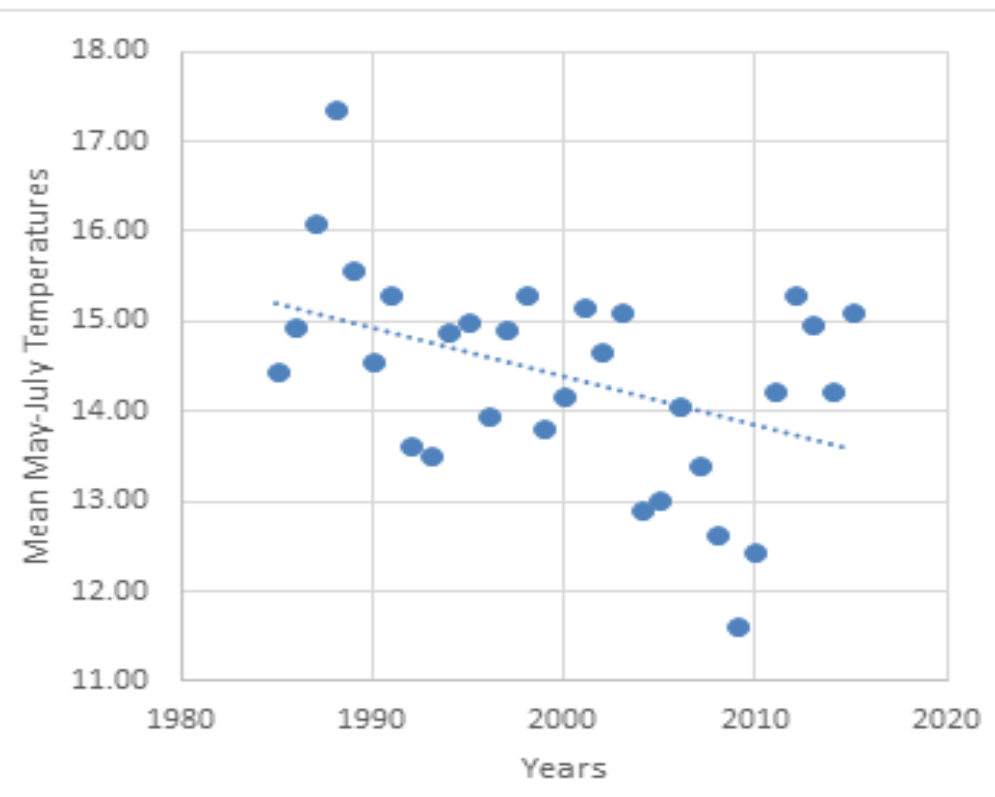

Figure 8(a). Mean May-July temperatures

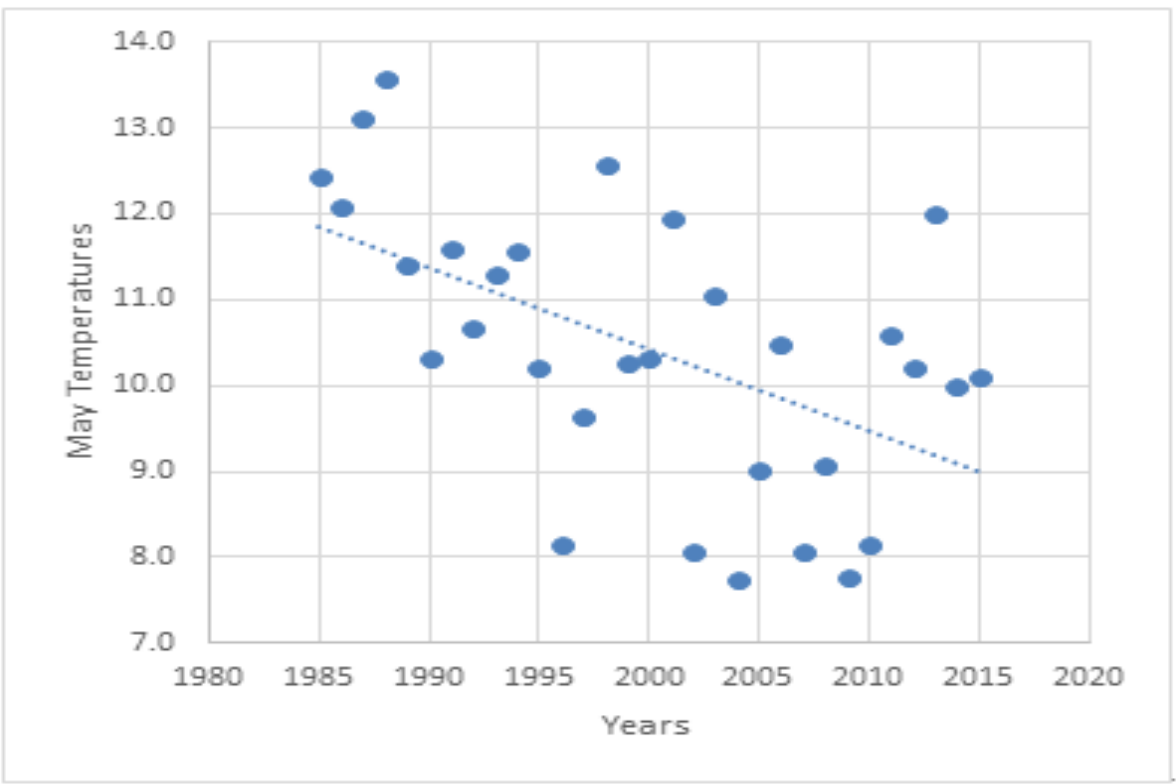

Figure 8(b). Mean May temperatures 
Figure 9(a) and 9(b) reveal how the canola area has tripled between 1990 and 2015 while May temperatures have cooled close to $3^{\circ} \mathrm{C}$ between 1985 and 2015. The correlation between the harvested canola area and the decline in May temperatures is -0.32 significant at the $5 \%$ level. May temperatures in 1996, 2002, 2004, 2007, 2009 and 2010 were greater than 1. S.D. below the 31 -year mean of $10.4^{\circ} \mathrm{C}$. In those years, the harvested canola area averaged $14 \%$ below the previous record and never exceeded trend. The trends shown in Figure 7(b) and 8(b) suggest the area planted to canola could be exposed to an increased risk of spring frost damage in future years. Replanting of canola occurs when the crop is damaged by spring frost.

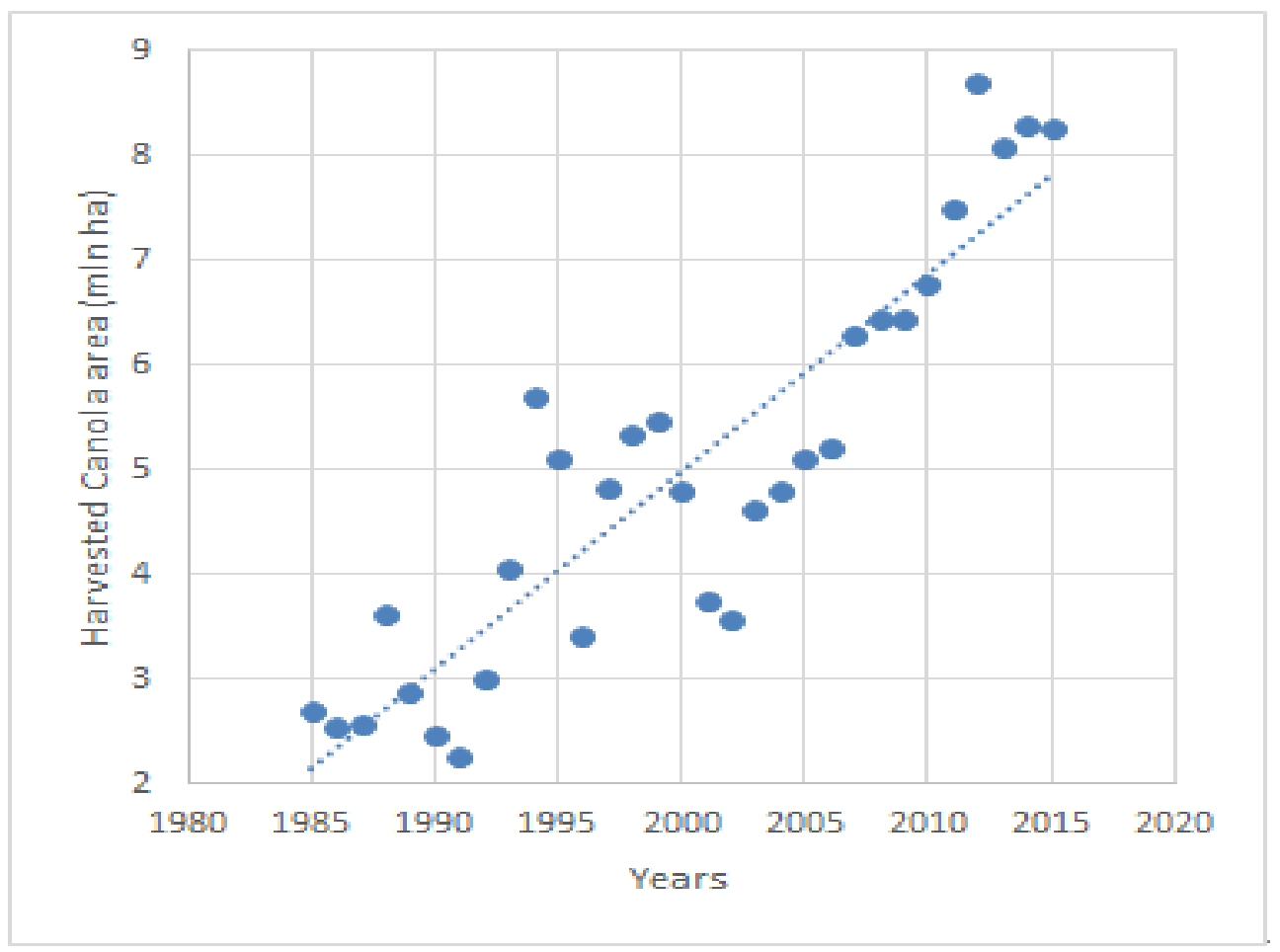

Figure 9(a). Increasing harvested area of canola

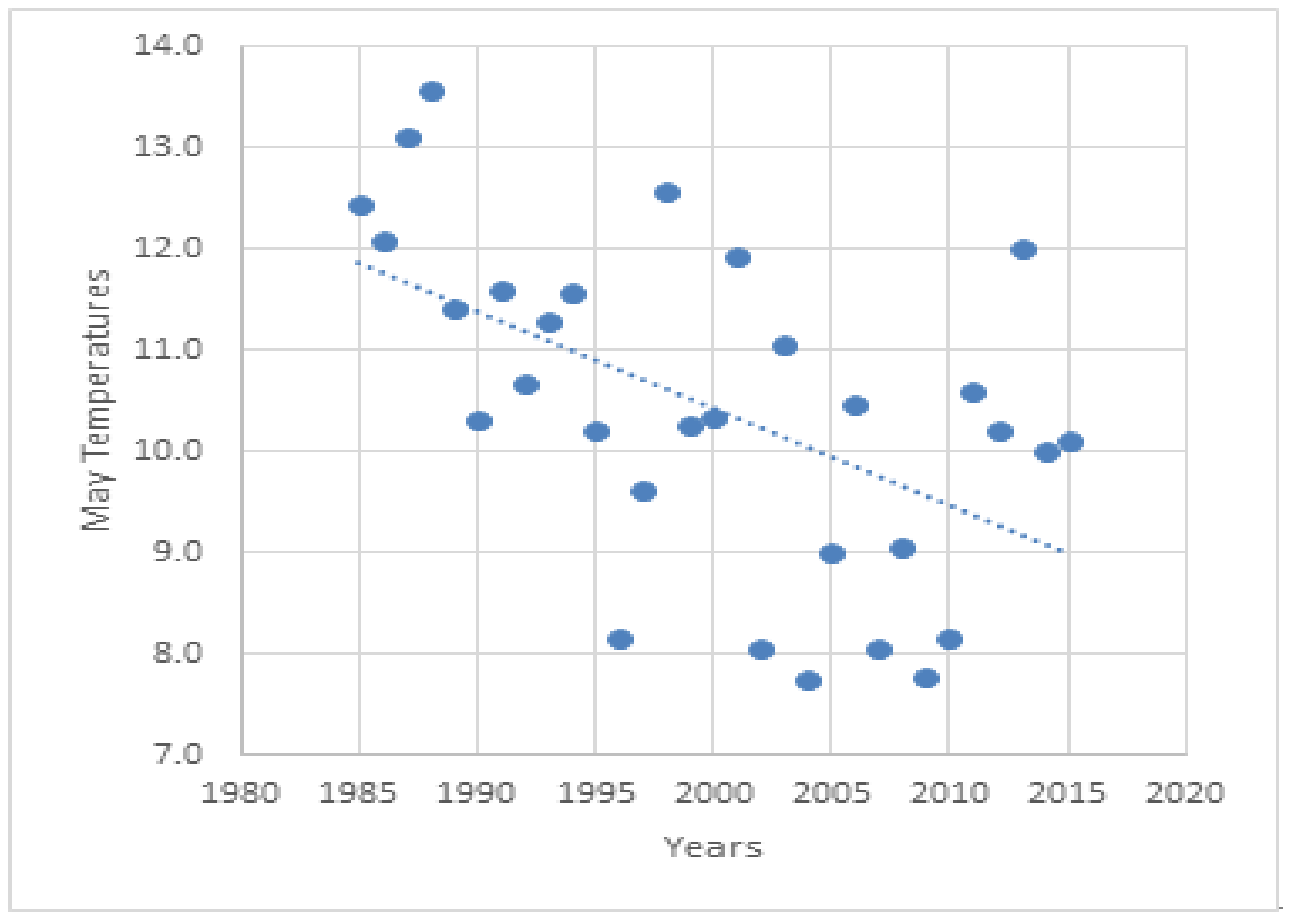

Figure 9(b). Declining May temperatures 


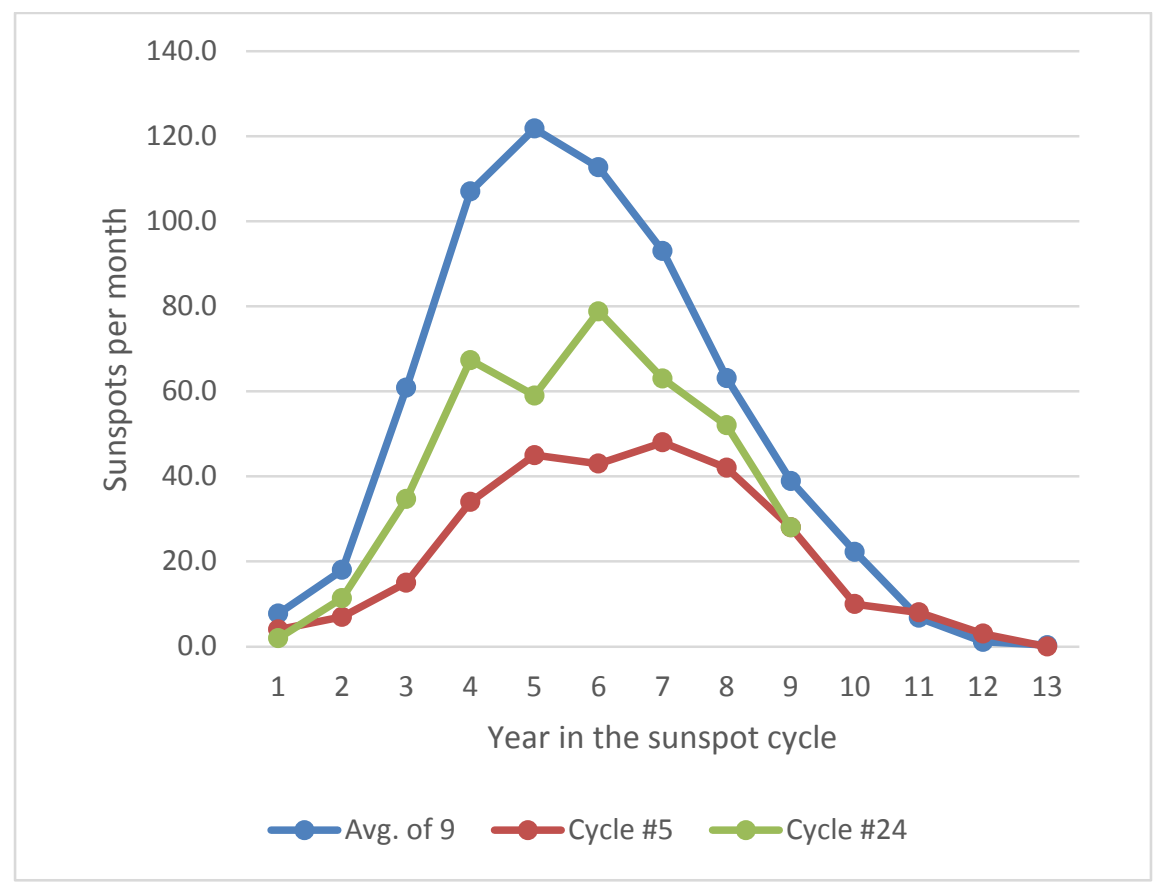

Figure 10. Top line is the average of nine sunspot cycles 1902-2009; Second line is sunspot cycle \#24, 2009-17; Third line is cycle \#5, 1798-1810, during the Dalton Minimum

Figure 10 compares (1) the average of nine 11-year sunspot cycles between 1902 and 2009 during the $20^{\text {th }}$ century and early part of the $21^{\text {st }}$ century (top line) with (2) sunspot activity from September of 2009 through January of 2017 into the $8^{\text {th }}$ agricultural year of sunspot cycle \#24 (second line) and (3) sunspot activity during sunspot cycle \#5 during the first half of the Dalton Solar Minimum (third line). To compare cycles \#5 and \#24 is consistent with the DeVries-Suess cycle of 210 years discussed by [22, 37, 38] which has its basis in carbon 14 dating. Mean monthly sunspot activity is organized by agricultural year which runs from September to August named by the year of harvest. It is clear from this figure that solar activity can be expected to decline through 2020 and with it most likely prairie growing season temperatures.

Why do we care about diminishing solar activity and a climate that could resemble that of the Dalton Minimum? The period 1775-1825 was an extraordinarily cold period in Europe [37]. Browning and Garriss [39] describe the brutally cold period of 1814-1823 that brought extremely cold weather and economic depression to northern Europe (22 sunspots per month during those years). Between 1800-1815 it has been estimated that China's population decreased from 430 to 380 million (a drop of 12\%) (18 sunspots per month in that period) and that neighboring Korea lost $30 \%$ of its population during the famine of 1812-13 [9]. That same winter Napoleon lost most of his Grand Army of 600,000 as a result of hunger and piecing cold in retreating from Moscow [40]. Manitoba's Selkirk Settlers arrived in the Red River Valley region between 1795 and 1823 and experienced frost, floods and locusts and probably would not have survived had it not been for help from the Aboriginal people and 60 million bison that roamed the Great Plains at that time $[41,42]$.

It is our opinion that Canadian prairie May-July temperatures will continue to decline in the next 5-10 years. What is suggested and recommended in light of this cooling trend? Firstly, that solar activity and temperature trends in the four ag eco zones be closely monitored and the relationship between the two be investigated in future research. Secondly, the first author recommends that Canadian prairie Agri-businesses take a more independent and active role in observing solar, temperature and agronomic related trends and be prepared to plant shorter growing season crops such as barley and lower quality winter wheat [43].

\section{Concluding Remarks}

In this study, we have identified summer weather and climate extremes on the Canadian prairies during May-July, the critical growing period for grain and oilseed crops such as wheat, canola and barley. The impact of weather extremes on various crops is different depending on the progress and maturity of these grains through the short summer of about 96 calendar days or 1,080 growing degree days (GDDs) for spring wheat. Besides large-scale atmosphere-ocean circulation patterns, we have identified the impact of solar variability leading up to wetter (drier) summers and its effect on yields and crop area. Solar variability may impact the four agro-ecological zones differently and there is a need to investigate this aspect further. The years 1961 and 1988 were among the most deficient in yield in the last 55 years. 
Besides low grain yields, grain quality is also an important parameter in marketing. Among some of the factors which have impacted grain production have been: early frost in spring and autumn, excess rains at ripening and harvest and cooler (hotter) summers. Unfavorable weather and climate parameters can and do affect grain yield and quality in most grain-exporting countries like Argentina, Australia and the U.S. The results of this study can provide useful guidance to various grain producing countries by encouraging them to suitably monitor the impacts of various terrestrial as well as extra-terrestrial factors (e.g., solar variability) on eventual grain yield and quality that affect marketing and trade.

\section{Acknowledgements}

We thank Walter Kremers and Beverly Phillips for their technical and proof reading assistance.

\section{Appendix: Selected Glossary of Terms}

The AP Index (API) refers to Planetary Amplitude of geomagnetic activity over the globe for a given day and is considered a proxy variable for solar activity. Its monthly value is considered more representative of the solar influence on global climate than monthly sunspot data. An observatory in Niemegh, Germany calculates official values of the AP index twice a day derived from measurements made at a number of stations worldwide of the variation in the geomagnetic field due to currents in the earth's ionosphere and to a lesser extent, in the earth's magnetosphere.

The Bermuda High has been described as an extension of the Azores High, a key aspect of the North Atlantic Oscillation (NAO), which is more expansive when the NAO is positive. Agro-Climatic Consulting (ACC) contends that a positive (negative) NAO tends to prevent (assist) moisture from entering North America through the Gulf of Mexico. See also the North Atlantic Oscillation.

Cloud Forcing Theory: Svensmark and Friis-Christensen [21] and Svensmark and Calder [22] describe the mechanism by which the sun influences the earth's climate wherein low (high) solar activity is associated with increased (decreased) cosmic rays, which assists (reduces) the formation of low-level cloud on a global scale. Georgieva [34] demonstrated that the API is more representative of solar activity than a monthly count of sunspots. Hence, it can be used as a proxy variable for solar variability. In short, when the monthly sunspot count or API is low (high) one can expect increased (decreased) low-level cloud globally.

DeVries-Suess Cycle of 200 Years: DeVries first demonstrated the time variation in atmospheric inventory of carbon 14 in tree contents in 1958. The carbon 14 isotopes were named "radiocarbon" by W. F. Libby, who developed radiocarbon dating. His research team also found that carbon 14 was a product of cosmic ray bombardment. Libby was awarded the Nobel Prize in Chemistry in 1960. Suess and Linick noted that the carbon isotope in wood cellulose in an annual tree ring corresponded remarkably well to $\mathrm{CO}_{2}$ in the atmosphere at the time. "When the sun is lazy, more cosmic rays reach earth, which seeds clouds and carbon 14 production goes up," to paraphrase Svensmark. Upland peat in southern Scotland provides a climate record over 5,500 years, revealing a 210-year cycle of alternating wet-cool and warm cycles. Sources: [22, 37. 38].

El Nino/Southern Oscillation (ENSO) in combination with the Indian monsoon system constitutes the largest single source of inter-annual climatic variability on a global scale with effects that are wide-ranging and often severe. The Southern Oscillation is the difference in sea level pressure between Darwin and Tahiti. A positive (negative) SOI is indicative of La Niña (El Niño) conditions: colder (warmer) than normal sea surface temperatures in the east equatorial Pacific. The El Nino 3.4 region is most commonly used. Bjerknes in the late 1960s fused the Southern Oscillation concept with that of warmer or colder than normal sea surface temperatures in the east equatorial Pacific. Hence, the phenomenon is called the El Nino/Southern Oscillation. Research has shown that if El Nino (La Nina) conditions are evident during the spring and summer months, the tendency is to favor (disfavor) rainfall during the Canadian prairie summer months.

The Madden Julian Oscillation (MJO) is a 30-day to 60-day intra-seasonal oscillation (a six-week cycle) which travels eastwards at approximately 13 miles/hour (6 meters/second) through the atmosphere over the Indian and Pacific Oceans. A wet phase of enhanced precipitation follows a dry phase when thunderstorm activity is suppressed.

It is hypothesized, for example, that a positive (negative) MJO in February at $120^{\circ} \mathrm{W}$ (near the North American west coast) appears to suppress (enhance) June-July precipitation over the Canadian prairies related to a six-week periodicity. The wettest time of the year over the prairies is around June 21 at high sun when a trough normally occurs on the west coast as part of the annual cycle. In the case of a positive MJO in February, repetition of the MJO six-week cycle around June 21 would serve to force a ridging pattern that acts against normal troughing associated with the annual cycle, resulting in a drier June-July.

Meridian Flow is the general circulation (denoted by the 564-isobaric pressure line) that crosses 20 degrees latitude. There is large amplitude in the jet stream.

North Atlantic Oscillation (NAO). The positive phase of the NAO reflects below normal heights and pressure across the high latitudes of the North Atlantic and above normal heights and pressure over the central North Atlantic, the eastern U.S. and western Europe. The negative phase reflects an opposite pattern of height anomalies over these regions. See also Bermuda High.

The Pacific North American Teleconnection Index (PNA) is a derivative index of the El Niño/Southern 
Oscillation index and is typically positive during El Nino and negative during La Nina. A positive (negative) PNA pattern is indicative of a strong (weak) Aleutian Low influence, which in turn forces a ridge (leads to Siberian expresses) over the prairie region. A positive (negative) PNA pattern is associated with mild (cold) winters over the Canadian prairies. During the April to May period research has shown that zonal flow (negative PNA) is associated with wetter, cooler weather while meridian flow is associated with drier, hotter weather over the Canadian prairies.

Pacific Decadal Oscillation (PDO) operates through a change in the location of warm and cold water in the Pacific. When the PDO index is positive (negative), waters in the north central Pacific Ocean tend to be cool (warm), and waters along the west coast of North America tend to be warm (cool) which alters the path of the jet stream. The effects of the PDO are most drastic in the Pacific Northwest, whereby positive PDO generally correlates with lower (higher) than average rainfall and higher (lower) than average air temperatures over the Canadian prairies. A positive (negative) PDO is conducive to meridian (zonal) flow and drier (wetter) conditions similar to the PNA influence. The positive or negative phase of the PDO can persist a decade or more. The PDO index has been positive since January of 2014.

The Quasi-Biennial Wind Oscillation (QBO), often referred to as the stratospheric wind reversal, was discovered in the early 1960s. Measured at Singapore, it is a reversal in winds at the top of the atmosphere, blowing one direction for about 13 months and then reversing. It is an important factor in foreshadowing Indian monsoon rainfall and recently demonstrated as a factor determining Canadian prairie rainfall. The strength of the QBO is measured at various levels of atmospheric pressure with the 30 and $50 \mathrm{mb}$ levels most commonly used.

Ridge: A ridge can be described as a mountain of warm air at the $500 \mathrm{mb}$ level halfway up into the atmosphere.

Zonal Flow: There is a rapid west to east motion of the general circulation across longitudes. There is little if any amplitude in the jet stream.

\section{REFERENCES}

[1] Padbury, G. A., Waltman, S., Caprio, J., Coen, G., McGinn, S., Mortengenson, D., Nielson, G., and Sinclair, R., 2002. Agro ecosystems and land resources of the northern Great Plains, Agronomy Journal, 94, pp. 251-261.

[2] Stefanski, R, et al., 1994. Major world crop areas and climatic profiles. World Agricultural Outlook Board, U.S. Department of Commerce, Agricultural Handbook No. 664.p.279

[3] Strahler, A. N., 1975. Physical Geography $4^{\text {th }}$ ed. John Wiley and Sons. p. 643

[4] Raddatz, R. L., and Khandekar, M. L., 1977. Numerical simulation of cold easterly circulations over the Canadian
Western Plains using a mesoscale boundary layer model. Boundary Layer Meteorology 11, pp. 307-327.

[5] Robertson, G. W., 1974. Wheat yields for 50 Years at Swift Current, Saskatchewan, in Relation to Weather. Canadian Journal of Plant Science, 54, pp. 625-650.

[6] Nemanishen, W., 2002. Red River Basin Super Floods and Super Droughts. A Report. PFRA, Agriculture Canada.

[7] Khandekar, M. L., 2004. Canadian Prairie Drought: A climatological assessment. Report prepared for Alberta Environment, Edmonton, Canada, p. 37.

http://www.gov.ab.ca/env/

[8] Sauchyn, D. J., and Skinner, W. R., 2001. A proxy record of drought severity for the southwestern Canadian Plains. Canadian Water Resources Journal, 26, pp. 253-273.

[9] Winkless, N., and Browning, I., 1975. Climate and the Affairs of Men. Harper Magazine Press.p.228

[10] Nemanishen, W., 1998. Drought in the Palliser Triangle (A Primer Report), PFRA, Agriculture Canada.

[11] Wheaton, E., 2011. The 1999-2005 Canadian Prairies Drought: Science, Impacts and Lessons, Drought Research Initiative, R. Stewart and R. Lawford (Eds.), Department of Environment and Geography, Univ. of Manitoba, Winnipeg.

[12] Curry, R. G., 1984. Periodic (18.6-year) and cyclic (11-year) induced drought and flood in western North America. $J$ of Geophysical Research, 89, 7215-7230.

[13] Curry, R. G., 1990. Deterministic signals in precipitation records from the American corn belt. Int'l J of Climatology, 10, pp. 179-189.

[14] Lean, J., Beer, J. and Bradley, 1995. Reconstruction of solar irradiance since 1610: Implications for climate change. Geophysical Research Letters, 22, pp. 3195-3198.

[15] Lean, J., and Rind, D., 1998. Climate forcing by changing solar radiation. $J$ of Climate 11, pp. 3069-3094.

[16] Meehl, G. A., et al., 2003. Solar and greenhouse gas forcing and climate response in the twentieth century. J of Climate, 16, pp. 426-444.

[17] Khandekar, M. L., et al., 2005. The global warming debate: A review of the state of science. Pure and Applied Geophysics, 162, pp. 1557-1580.

[18] IPCC 2007: Climate Change 2007: The physical science basis. Contribution of the Working Group I to the fourth assessment report of the Intergovernmental Panel on Climate Change IPCC: Ed. by S Solomon et al., Cambridge University Press.

[19] Curry, B.W., and Venkatarangan, P., 1978: Relationship between solar disturbances and precipitation on the Canadian Prairies. Institute of Space and Atmospheric Studies, University of Saskatchewan Archives, Saskatoon, Canada.

[20] Garnett, E. R., et al., 2006. Correlates of Canadian Prairie summer rainfall: Implications for crop yields. Climate Research 32, pp. 25-33

[21] Svensmark, H., and Friis-Christensen, E., 1997. Variation of cosmic ray flux and global cloud cover: A missing link in solar-climate relationship. $J$ of Atmospheric and Solar-Terrestrial Physics. 59, pp. 1255-32. 
[22] Svensmark, H., and Calder, N., 2007. The Chilling Stars: A new theory of climate change. Icon Books, Cambridge, UK. p. 246

[23] Garnett, E. R., and Khandekar, M. L., 1992. The impact of large-scale atmospheric Circulations and anomalies on Indian monsoon droughts and floods and on world grain yields - a statistical analysis. Agricultural and Forest Meteorology 61, pp. 112-128.

[24] Peterson, R. F., 1965. Wheat, Interscience Publishers, New York.

[25] King, W. J., 1987. Irrigation of Cereal Crops, Saskatchewan Water Corporation, Outlook, Saskatchewan.

[26] Garnett, E. R., 2002. Long lead forecasting of precipitation and wheat yields in Saskatchewan using teleconnection indices, M.Sc. thesis, Geography Department, Univ. of Saskatchewan, Saskatoon.

[27] Garnett, E. R., and Khandekar, M. L., 2015. Determinants of summer weather extremes over the Canadian Prairies: Implications for long lead grain forecasting. Natural Hazards 76 DOI:10.1007/s11067-014-1543-3.

[28] Garnett, E. R., 2004. The Science, Impacts and Monitoring of Drought in Western Canada. Impact of Drought on Grain Yields in Canada and Elsewhere. Ed. by D. Sauchyn, M. Khandekar, and R. Garnett. Canada Plains Research Center, University of Regina, Regina, Saskatchewan.

[29] Saiyid, I. M., Bullock, P. R., Sapistein, H. D., Finlay, G. J., and Jarvis, C. K., 2009. Thermal time models for estimating wheat phenological development and weather-based relationships to wheat quality, Can. J. of Plant Sci., 89, pp. 429-439.

[30] Notes of K. H. Tipples, Canadian Grain Commission, circa 1995.

[31] Brimelow, J., and Hanesiak, J., 2011 The 1999-2005 Canadian Prairies Drought: Science, Impacts and Lessons, Drought Research Initiative, R. Stewart and R. Lawford (Eds.), Department of Environment and Geography, Univ. of Manitoba, Winnipeg.

[32] The Western Producer, Western Producer Publications
November 24, 2016 Vol. 94 No 47 p. 8

[33] Allan, R., Lindsey, J., and Parker, D., 1996. El Nino/Southern Oscillation and Climate Variability. Collingwood, Victoria, Australia: CSIRO Publishing.

[34] Georgieva, K., Bianci, C., and Kirov, B., 2005. Once again about global warming and solar activity, Mem. S. A. It. (Società Astronomica Italiano), 76, p. 969.

[35] Hughes, A. M., Khandekar, M. L. and Ollier, C., 2014. About Face - Why the world needs more $\mathrm{CO}_{2}$ : The Failed Science of Global Warming. Two Harbors Press, Minneapolis, Minnesota, p. 327.

[36] Archibald, D., 2009. Solar 2009 Cycle 24: Expectations and Implications. Energy and Environment Vol. 20, No $1 \& 2$.

[37] Plimer, I., 2009. Heaven and Earth - global warming the missing science. Connor Court Publishing, Ballan, Victoria, Australia. p503.

[38] Wei-Hock Soon, W., and Yaskel, S. H., 2003. The Maunder Minimum and the Variable Sun-Earth Connection. World Scientific Publishing, 5 Toh Tuck Link, Singapore.

[39] Browning, I., and Garriss, E M., 1981. Past and Future History-A Planners Guide. Fraser Publishing, Burlington, Vermont.

[40] The World Book World Encyclopedia, 1966, N-0 Napoleon 1, p. 15.

[41] Garnett, E.R. and Khandekar M.L. 2010: The Summer of 2010: Wettest on the Canadian prairies in 60 years! A preliminary assessment of cause and consequence. Canadian Meteorological and Oceanographic Society (CMOS) Bulletin. December 2010. Vol.38. N o6

[42] Green, Wilson F. 1974. Red River Revelations. A chronological account of early events leading to the discovery, occupation, and development of the Red River Settlement. Hignell Printing Ltd., Winnipeg, Manitoba 252 pp

[43] Archibald, D., 2014. Twilight of Abundance: Why Life in the $21^{\text {st }}$ century will be Nasty, Brutish and Short. Regnery Publishing, Washington D.C. p. 208. 